\title{
JULY 1976
}

SIXTEENTH YEAR - No. 184
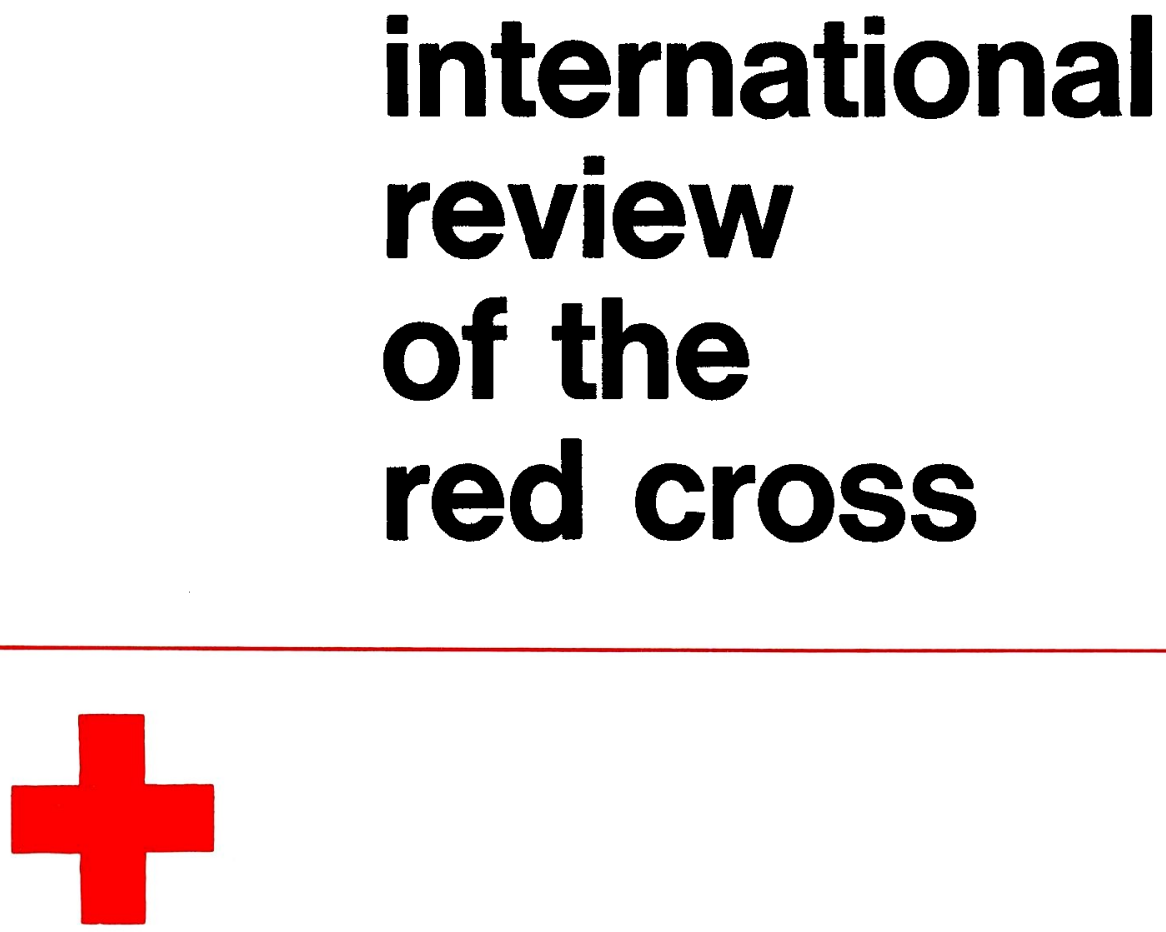

INTER ARMA CARITAS

GENEVA

INTERNATIONAL COMMITTEE OF THE RED CROSS FOUNDED IN 1863 


\section{INTERNATIONAL COMMITTEE OF THE RED CROSS}

Mr. ALEXANDRE HAY, Lawyer, former Director-General of the Swiss National Bank, President (member since 1975).

Mr. JEAN PICTET, Doctor of Laws, Chairman of the Legal Commission, Director of the Henry-Dunant Institute, Associate Professor at the University of Geneva, Vice-President (1967)

Mr. HARALD HUBER, Doctor of Laws, Federal Court Judge, Vice-President (1969)

Mrs. DENISE BINDSCHEDLER-ROBERT, Doctor of Laws, Professor at the Graduate Institute of International Studies, Geneva, Judge at the European Court of Human Rights (1967)

Mr. MARCEL A. NAVILLE, Master of Arts, ICRC President from 1969 to 1973 (1967)

Mr. JACQUES F. DE ROUGEMONT, Doctor of Medicine (1967)

Mr. ROGER GALLOPIN, Doctor of Laws, former ICRC Director-General (1967)

Mr. WALDEMAR JUCKER, Doctor of Laws, Secretary, Union syndicale suisse (1967)

Mr. VICTOR H. UMBRICHT, Doctor of Laws, Managing Director (1970)

Mr. PIERRE MICHELI, Bachelor of Laws, former Ambassador (1971)

Mr. GILBERT ETIENNE, Professor at the Graduate Institute of International Studies and at the Institut d'études du développement, Geneva (1973)

Mr. ULRICH MIDDENDORP, Doctor of Medicine, head of surgical department of the Cantonal Hospital, Winterthur (1973)

Mrs. MARION BOVÉE-ROTHENBACH, Master of Social Work (University of Michigan), Reader at the Ecole des Sciences sociales et politiques of the University of Lausanne (1973)

Mr. HANS PETER TSCHUDI, Doctor of Laws, former Swiss Federal Councillor (1973)

Mr. HENRY HUGUENIN, Bank Manager (1974)

Mr. GOTTFRIED DE SMIT, Managing Director (1974)

Mr. JAKOB BURCKHARDT, Doctor of Laws, Minister Plenipotentiary, Chairman of the Council of Federal Polytechnic Schools (1975)

Mr. THOMAS FLEINER, Master of Laws, Professor at the University of Fribourg (1975)

Mr. HERBERT LÜTHY, Doctor of Philosophy, Professor of History at the University of Basle (1975)

Honorary members: Miss LUCIE ODIER, Honorary Vice-President;

Messrs. HANS BACHMANN,

GUILLAUME BORDIER, PAUL CARRY,

Mrs. MARGUERITE GAUTIER-VAN BERCHEM,

Messrs. ADOLPHE GRAEDEL, ÉDOUARD DE HALLER, ERIC MARTIN,

RODOLFO OLGIATI, MAX PETITPIERRE, PAUL RUEGGER,

DIETRICH SCHINDLER, FRÉDÉRIC SIORDET, ALFREDO VANNOTTI.

\section{EXECUTIVE COUNCIL}

Mr. ROGER GALLOPIN, President

Mr. VICTOR H. UMBRICHT, Vice-President

Mrs. DENISE BINDSCHEDLER-ROBERT

Mr. GILBERT ETIENNE

Dr. ULRICH MIDDENDORP

Mr. JEAN PICTET

Mr. GOTTFRIED DE SMIT

Mr. PIERRE MICHELI, Deputy member 


\section{INTERNATIONAL REVIEW OF THE RED CROSS}

\section{CONTENTS}

JULY 1976 - No. 184

\section{INTERNATIONAL COMMITTEE OF THE RED CROSS}

IN THE RED CROSS WORLD

MISCELLANEOUS

BOOKS AND REVIEWS
Diplomatic Conference (third session)

External activities:

Africa - Middle East - Latin America - Asia

- North America. 337

In Geneva:

Mr. Eric Martin, Honorary Member of ICRC . 346

A Tribute from the International Committee . . 348

Accessions to the Geneva Conventions . . . . . 349

Standing Commission of the International Red Cross . . . . . . . . . . . . 350

Seventh Regional Meeting of Red Cross Societies in Managua . . . . . . . . . . . . . . . . . 352

United States . . . . . . . . . . . . . . . . 353

Bangladesh . . . . . . . . . . . . 355

International Covenants on Human Rights . . . 356

Mutual Assistance and International Solidarity . 368

Problems of International Humanitarian Law . . 372

For a Fairer Sharing of Health Resources . . . 375

Health and Human Rights . . . . . . . . . . 377 
REVUE INTERNATIONALE

DE LA CROIX-ROUGE

\section{REVISTA INTERNACIONAL} DE LA CRUZ ROJA

\section{EXTRACTS FROM} THE REVIEW

\section{GERMAN}

INTERNATIONAL REVIEW OF THE RED CROSS
The French and Spanish editions, also issued every month, may be obtained at the same price.

Das Rote Kreuz und die Umwelt - Internationaler Suchdienst - Das Internationale Komitee vom Roten Kreuz ehrt Jakob Haug - Teilnahme an den Genfer Abkommen - VIII. Regionaltagung der Arabischen Rotkreuz- und Rothalbmondgesellschaften - II. Konferenz der Rotkreuz- und Rothalbmondgesellschaften der Balkanländer.

The International Review is published each month by the International Committee of the Red Cross

17, avenue de la Paix, 1211 Geneva, Switzerland Postal Cheque No. 12 - 1767.

Annual subscription: Sw. Fr. 30.- (\$10.-)

Single copy Sw. Fr. 3.- (\$1.-)

EDITOR: J.-G. LOSSIER

The International Committee of the Red Cross assumes responsibility only for material over its own signature. 